\title{
INDEX TO VOLUME 37 (1978)
}

\section{CONTRIBUTORS}

Aczél, Tamás (reviews) 2:358-59, 3:518-19

Adams, Jan S. "Institutional Change in the 1970s: The Case of the USSR People's Control Committee" 3:457-72; (review) $1: 134$

Adler, Philip J. (review) 4:704-5

Albrecht-Carrié, René (review) 3:496-97

Allen, Richard E. (review) 1:155-56

Alston, Pat (review) 3:512

Amalrik, Andrei (review) 2:316-17

Anweiler, O. (review) 2:315

Auty, Robert (review) 1:157-58

Avakumovic, Ivan (review) 2:296

Avrich, Paul (review) 1:125-26

Backer, John H. (review) 3:502

Bailes, Kendall E. "Soviet Design: A Comment and an Alternative View" 4:595-601

Bak, Janos M. (review) 3:525-26

Balogh, Eva S. (review) 4:700-702

Baran, Henryk (review) 3:536-37

Baras, Victor. "Stalin's German Policy After Stalin" 2:259-67

Beaujour, Elizabeth Klosty (review) 1:17273

Bell, John D. (review) 2:338-39

Bowlt, John E. (reviews) 2:351-53, 3:545-46

Brada, Josef C. (review) 4:691-92

Breslauer, George (review) 1:132-33

Bristol, Evelyn (review) 1:170

Brown, Deming (review) 1:170-71

Brown, Edward J. (review) 3:534-35

Browning, Gary L. (review) 2:348-49

Bruegel, J. W. (review) 2:322-23

Burger, Robert, et al. "Reference Books of 1976-77: A Selection" 3:548-53

Burks, R. V. (review) 2:335

Bushkovitch, Paul. "Taxation, Tax Farming, and Merchants in Sixteenth-Century Russia" 3:381-98; (review) 2:321-22

Bynum, David E. (review) 1:173-74

Byrnes, Robert F. "Archibald Cary Coolidge: A Founder of Russian Studies in the United States" 4:651-67

Campbell, John C. (review) 3:531-32

Campbell, Robert (review) 2:314

Carden, Patricia (obituary) 4:729-30

Carr, E. H. (review) 1:126-27

Choldin, Marianna Tax, et al. "Reference Books of 1976-77: A Selection" 3:548-53

Cienciala, Anna M. (review) 4:695-96

Clark, Cal (review) 3:510-11

Clark, M. Gardner (review) 1:142-43

Clarke, James F. (review) 4:711-12

Clawson, Robert W. (review) 4:685-86

Congdon, Lee (review) 2:331-32

Critchlow, James (review) 1:145-46

Croan, Melvin (review) 2:306-7

Curtis, James M. (review) 3:535
Czerwinski, E. J. (review) 3:540-41

Dallin, Alexander (review) 2:301-3

Davies, Norman (review) 2:298

Davison, Roderic H. (review) 1:162-63

Deak, Istvan (review) 3:526-27

Despalatović, Elinor Murray (review) 2:334

Dossick, Jesse J. "Doctoral Dissertations on Russia, the Soviet Union, and Eastern Europe Accepted by American, Canadian, and British Universities, 1977-1978" 4:73348

Dreisziger, N. F. (review) 2:318

Dunlop, John B. (reviews) 1:168-69, 3:53738

Dunn, Stephen P. (review) 4:689-90

Eekman, Thomas (review) 1:174-75

Ellman, Michael (review) 3:512-13

Ernst, Maurice C. (obituary) 4:731

Ewing, Catharine V. (review) 4:692

Fallows, Thomas. "Politics and the War Effort in Russia: The Union of Zemstvos and the Organization of the Food Supply, 1914-1916" 1:70-90

Farmer, Kenneth C. (review) 3:521-22

Fauriol, Georges A. (review) 1:140-41

Fellmann, Jerome D. (review) $2: 315$

Feuer, Kathryn B. (review) 1:167-68

Fichtner, Paula Sutter (review) 3:524-25

Field, Mark G. (review) 1:143-45; (obituary) $1: 182-83$

Fisher, Ralph T., Jr. (review) 2:316

Fitzpatrick, Sheila (review) 4:675-76

Folejewski, Z. (review) 2:340-41; (obituary) 4:730-31

Foot, M. R. D. (review) 1:130-31

Freeborn, Richard (review) 1:165-66

Freedman, Paul W. (review) 4:696-97

Friedberg, Maurice (review) 1:169-70

Garver, Bruce (review) 2:326-27

Gati, Charles (review) 4:680-81

Geanakoplos, Deno J. (review) 2:339

Geary, Patrick J. (review) 3:495

George, Emery E. (review) 4:718-20

Gibian, George. "The Urban Theme in Recent Soviet Russian Prose: Notes Toward a Typology" 1:40-50; (reviews) 2:354-55, 3:538-39, 4:716-17

Gill, Graeme J. "The Failure of Rural Policy in Russia, February-October 1917" 2:24158

Gitelman, Zvi (review) 1:136-37

Gladney, Frank Y. (review) 4:724-25

Granick, David. "What Is Good Design?: A Comment" 4:584-86

Grimsted, Patricia Kennedy (review) 1:14648

Halpern, Joel M. (review) 2:291-92

Hamburg, G. M. "The Crisis in Russian Agriculture: A Comment" 3:481-86 
Hanak, Harry (review) 4:697-98

Hanhardt, Arthur M., Jr. (review) 1:149

Haywood, Richard Mowbray. "The 'Ruler Legend': Tsar Nicholas I and the Route of the St. Petersburg-Moscow Railway, 1842-1843" 4:640-50

Held, Joseph (reviews) 1:150, 4:698-99

Herspring, Dale R. (review) 1:134-35

Hertz, Allen Z. (review) 4:703-4

Hewett, Edward A. "Most-Favored Nation Treatment in Trade Under Central Planning" 1:25-39

Hitchins, Keith (review) 3:528-29; (obituary) $1: 184-85$

Hoensch, Jörg K. (review) 2:325-26

Hoisington, Thomas $H$. (review) 2:355-56

Hook, Sidney (reviews) 2:307-8, 2:323-25

Humesky, Assya (review) 2:341-43

Hutchings, Raymond. "Soviet Design: The Neglected Partner of Soviet Science and Technology" 4:567-83; "Reply" 4:602-3; (review) $1: 143$

Jackson, George (review) 1:161-62

Jackson, Kenneth T. (review) 2:327-28

Johannsen, Robert W. (review) 4:693

Kadić, Ante. "The Stalin-Tito Conflict as Reflected in Literature" 1:91-106

Kaser, Michael (review) 2:311-13

Kass, Ilana, and Norman Kass (review) $1: 141-42$

Kazemzadeh, Firuz (review) 4:668-69

Keep, John (review) 1:124-25

Kime, Steve F. (review) 3:506-7

Kingston-Mann, Esther (review) 2:294-95

Király, Béla K. (review) 1:156-57

Kleimola, Ann (reviews) 2:291, 3:496

Kreindler, Isabelle (review) 4:686-87

Krekić, Bariša (review) 4:705-6

Kruzel, Joseph J. (review) 3:504-5

Krzyżanowski, Jerzy R. (reviews) 1:164, 2:358

Kulesov, Catherine (review) 2:345

Kulski, W. W. (review) 1:150-51

Lammers, Donald (review) 2:296-97

Lazarcik, Gregor (review) 3:523-24

Leed, Richard L. (review) 2:362-63

Lehrman, Edgar H. (review) 3:533-34

Leich, Harold, et al. "Reference Books of 1976-77: A Selection" 3:548-53

Lencek, Nina A. (review) 1:148-49

Levaco, Ronald (review) 4:725-26

Levin, Alfred (obituary) 2:367

Lowenthal, Richard (review) 4:682-83

Lubrano, Linda L. (review) 2:310-11

Lunt, Horace G. (review) 4:723-24

Lupinin, Nickolas (obituary) 1:183-84

McIntyre, Robert J. (review) 3:517-18

Mamatey, Victor S. (obituary) $4: 732$

Marantz, Paul (review) 4:679-80

Mark, Thomas R. (reviews) 4:720, 4:721

Marrese, Michael (review) 3:515-17

Mastny, Vojtech (review) 4:681-82
Matejić, Mateja (review) 4:721-22

Mendelsohn, Ezra (review) 4:694-95

Meriage, Lawrence $P$. "The First Serbian Uprising (1804-1813) and the NineteenthCentury Origins of the Eastern Question" 3:421-39

Merritt, Richard L. (review) 3:519-20

Meyer, Alfred G. (review) 4:674-75

Miller, David H. (review) 4:671

Miller, Laurence H., et al. "Reference Books of 1976-77: A Selection" 3:548-53

Monas, Sidney (review) 4:683-85

Moravčevich, Nicholas (review) 3:543

Moskoff, William. "Sex Discrimination, Commuting, and the Role of Women in Rumanian Development" 3:440-56

Mote, Max (review) 2:308-9

Motyl, Alexander J. "The Rural Origins of the Communist and Nationalist Movements in Wolyń Województwo, 1921-1939" $3: 412-20$

Myrsiades, Kostas (review) 4:722-23

Naby, Eden. "Bobodzhon Gafurovich Gafurov, 1908-1977" 2:283-85

Nakhimovsky, Alice Stone. "The Ordinary, the Sacred, and the Grotesque in Daniil Kharms's The Old Woman" 2:203-16

Naylor, Kenneth E. (review) 1:176

Novak, Bogdan C. (reviews) 4:708-9, 4:710

Nove, Alec (review) 1:128-30

O'Connor, Katherine Tiernan. "Boris Pasternak's My Sister-Life: The Book Behind the Verse" 3:399-411

Oinas, Felix J. (reviews) 1:159-60, 2:360

Oppenheim, Samuel A. (review) 4:669-70

Pachuta, June E. "Reference Books of 197677: A Selection" 3:548-53

Parrish, Michael (review) 1:138

Paxton, Roger (review) 1:158-59

Pech, Stanley Z. (reviews) 1:153-54, 3:52728

Perina, Rudolf Vilem (review) 1:152-53

Perkowski, Jan Louis (review) 2:361-62

Pertzoff, Margaret $H$. (review) 2:290

Petrovich, Michael B. "Croatian Humanists and the Writing of History in the Fifteenth and Sixteenth Centuries" 4:624-39

Pintner, Walter M. (review) 4:672

Presseisen, Ernst L. (review) 3:501-2

Psomiades, Harry J. (review) 2:340

Pulzer, Peter (review) $1: 154-55$

Raeff, Marc (review essay) 1:116-19; (review) $1: 128$

Ramer, Samuel C. (reviews) 1:121-23, 2:300-301

Ransel, David L. (reviews) 3:498-500, 3:500

Rasmussen, Karen. "Catherine II and the Image of Peter I" 1:51-69

Reshetar, John S., Jr. (review) 4:670-71

Rich, Norman (review) 1:151-52

Rigby, T. H. "The Soviet Regional Leader- 
ship: The Brezhnev Generation" 1:1-24; (reviews) $3: 507-9,3: 509-10$

Roberts, Walter R. (review essay) 3:49194

Rosefielde, Steven (review essay) 2:28689; (reviews) 2:313, 3:529-30

Rosen, Nathan (review) 4:712-15

Rosenthal, Bernice Glatzer (review) 2:34546

Rowe, William W. (review) 2:347-48

Rowney, Don Karl, and Edward G. Stockwell. "The Russian Census of 1897: Some Observations on the Age Data" 2:217-27

Salisbury, Harrison, E. (review) 1:131-32

Saul, Norman E. (review) 1:138-40

Scatton, Ernest A. (review) 3:544-45

Schamschula, Walter (review) 1:164-65

Schwartz, Morton (review) 3:502-3

Scott, William E. (review) 2:317-18

Senkevitch, Anatole, Jr. "Art, Architecture, and Design: A Commentary" 4:587-94

Senn, Alfred Erich (review) 4:677; (obituary) $3: 555$

Serfaty, Simon (review) 2:336-37

Seroka, James H. "Prospects for Stability in Post-Tito Yugoslavia" 2:268-82; (review) 3:532-33

Setchkarev, Vsevolod (review) 4:715-16

Seton-Watson, Hugh (reviews) 2:328-29, 4:702-3

Shaw, J. Thomas (obituary) 3:554-55

Shneidman, N. N. (review) 2:346-47

Shtohryn, Dmytro M., et al. "Reference Books of 1976-77: A Selection" 3:548-53

Silbajoris, Rimvydas (review) $1: 163$

Simirenko, Alex (review) 4:690-91

Simms, James Y., Jr. "On Missing the Point: A Rejoinder" 3:487-90

Sinanoglou, Ioannis (review) 2:329-30

Skrynnikov, R. G. "On the Authenticity of the Kurbskii-Groznyi Correspondence: A Summary of the Discussion" 1:107-15

Slater, John A. (review) 2:319-20

Smith, C. Jay (review) 2:299

Smith, D. Brent (review) 2:304-5

Socor, Vladimir (reviews) 2:337-38, 4:71011

Sokol, Elena (review) $2: 349-51$

Sonnenfeldt, Helmut (review) 2:303-4

Spahr, William J. (review) 3:505-6

Stammler, Heinrich A. (reviews) 1:171-72, 4:688-89

Stearns, Peter N. (review) 1:160-61

Steeves, Paul D. (review) 1:123-24

Stites, Richard (review) 3:497-98

Stockwell, Edward G., and Don Karl Rowney. "The Russian Census of 1897: Some Observations on the Age Data" 2:217-27

Stokes, Gale (reviews) 2:332-34, 3:530-31

Struk, Danylo Husar (review) 1:174

Stuart, Robert C. (review) 1:133-34

Suda, Zdenek (review) 2:309-10

Taborsky, Edward (review) 3:522-23

Terlecki, Tymon (review) 2:356-57
Terras, Victor (review) 2:343-44

Thompson, Ewa M. (review) 3:541-42

Treadgold, Donald W. (review) 1:120-21

Ulmen, G. L. (review) 3:513-15

Vardy, S. B. (review) 2:330-31

Vermes, Gabor (review) 4:699-700

Visson, Lynn (review) 4:717-18

Vucinich, Wayne S. (review) 4:706-8

Wade, Rex A. (review) 2:295-96

Walker, Angus (review) 4:672-73

Wasiolek, Edward (review) 1:167

Weissman, Neil B. "Rural Crime in Tsarist Russia: The Question of Hooliganism, 1905-1914" 2:228-40

Wellek, René (review) 3:542

Welsh, David (review) 3:539-40

Williams, Robert C. (review) 2:353-54

Wortman, Richard (review) 1:127

Wright, William E. (review) 2:320-21

Wynar, Bohdan S. (review) 3:520-21

Yaney, George L. (review) 4:674

Yergin, Angela Stent (review) 4:677-78

Zeldin, Mary-Barbara. "Chaadayev as Russia's First Philosopher" 3:473-80; (review) $4: 687-88$

Zelnik, Reginald E. (review) 2:292-93

Zile, Zigurds L. (review) 3:511

Zimmerman, William. "Dependency Theory and the Soviet-East European Hierarchical Regional System: Initial Tests" 4:604-23

\section{OBITUARIES}

Auty, Robert (Zbigniew Folejewski) 4:73031

Bauer, Raymond Augustine (Mark G. Field) 1:182-83

Belousow, Constantine G. (Nickolas Lupinin) 1:183-84

Greenslade, Rush V. (Maurice C. Ernst) 4:731

Haupt, Georges (Alfred Erich Senn) 3:555

Horna-Perman, Dagmar (Victor S. Mamatey) $4: 732$

Mathewson, Rufus Wellington, Jr. (Patricia Carden ) $4: 729-30$

Otetea, Andrei (Keith Hitchins) 1:184-85

Senn, Alfred (J. Thomas Shaw) 3:554-55

Tompkins, Stuart Ramsay (Alfred Levin) $2: 367$

\section{BOOKS REVIEWED}

van Ackern, Karl-Dieter. Bulat Okudžava und die kritische Literatur über den Krieg (N. N. Shneidman) 2:346-47

Allworth, Edward, ed. Nationality Group Survival in Multi-Ethnic States: Shifting Support Patterns in the Soviet Baltic Region (Catharine V. Ewing) 4:692

Andrić, Ivo. The Bridge on the Drina, trans. 
by Lovett F. Edwards (Nicholas Moravčevich) $3: 543$

Anrod, Werner. Kulturelle Integration im Ostblock: Ein Prozess zwischen Fortschritt und Rückschlag (Tamás Aczél) 3:518-19

Anweiler, Oskar, et al., eds. Die sowjetische Bildungspolitik von 1958 bis 1973: Dokumente und Texte (Pat Alston) 3:512

Auty, Robert, and Dimitri Obolensky, eds. An Introduction to Russian Language and Literature (Edgar H. Lehrman) 3:533-34

Bailey, Thomas A. The Marshall Plan Summer: An Eyervitness Report on Europe and the Russians in 1947 (John H. Backer) 3:502

Bajaja, Vladislav. Theoretische Grundlagen und praktische Entwicklung landwirtschaftlicher Betriebsgrössen in der Tschechoslowakei (Gregor Lazarcik) 3:523-24

Barry, Donald D., and Carol Barner-Barry. Contemporary Soviet Politics: An Introduction (Cal Clark) 3:510-11

Bater, James H. St. Petersburg: Industrialization and Change (Samuel $\mathrm{C}$. Ramer) 2:300-301

Bell, John D. Peasants in Power: Alexander Stamboliski and the Bulgarian Agrarian National Union (George Jackson) 1:16162

Berliner, Joseph S. The Innovation Decision in Soviet Industry (Michael Kaser) 2:311-13

Bettelheim, Charles. Class Struggles in the USSR: First Period 1917-1923 (Sheila Fitzpatrick) 4:675-76

Bettelheim, Charles. Les Luttes de classes en USSR: Deuxième période 1923-1930 (Sheila Fitzpatrick) 4:675-76

Bielfeldt, Sigrun. Die čechische Moderne im Frühwerk Saldas: Zur synchronen Darstellung einer Epochenschwelle (René Wellek) $3: 542$

Borowiec, Andrew. Yugoslavia After Tito (James H. Seroka) 3:532-33

Bosl, Karl, ed. Gleichgewicht, Revision, Restauration: Die Aussenpolitik der Ersten Tschechoslowakischen Republik im Europasystem der Pariser Vororteverträge (Harry Hanak) 4:697-98

Boyd, Alexander. The Soviet Air Force since 1918 (Michael Parrish) 1:138

Broido, Vera. Apostles Into Terrorists: Women and the Revolutionary Movement in the Russia of Alexander II (Richard Stites) 3:497-98

Brown, Archie, and Jack Gray, eds. Political Culture and Political Change in Communist States (Vojtech Mastny) 4:681-82

Brown, Archie, and Michael Kaser, eds. The Soviet Union Since the Fall of Khrushchev (Jan S. Adams) 1:134

Brown, Deming. Soviet Russian Literature since Stalin (George Gibian) 4:716-17

Bruce, James $\mathrm{B}$. The Politics of Soviet
Policy Formation: Khrushchev's Innovative Policies in Education and Agriculture (George Breslauer) 1:132-33

Budurowycz, Bohdan. Slavic and East European Resources in Canadian Academic and Research Libraries (Nina A. Lencek) $1: 148-49$

Bulgakov, Sergius. A Bulgakov Anthology (Stephen P. Dunn) 4:689-90

Calhoun, Daniel F. The United Front: The TUC and the Russians 1923-1928 (Norman Davies) 2:298

California Slavic Studies, vol. 10, 1:177

Campbell, F. Gregory. Confrontation in Central Europe: Weimar Germany and Czechoslovakia (Bruce Garver) 2:326-27

Campbell, John C., ed. Successful Negotiation: Trieste 1954. An Appraisal by the Five Participants (Simon Serfaty) 2:33637

The Canadian-American Review of Hungarian Studies, vol. 3, no. 2 (Fall 1976), $1: 177$

Chalidze, Valery. Criminal Russia: Essays on Crime in the Soviet Union (Zigurds L. Zile) $3: 511$

Chirot, Daniel. Social Change in a Peripheral Society: The Creation of a Balkan Colony (Peter N. Stearns) 1:160-61

Clark, Cal, and Robert L. Farlow. Comparative Patterns of Foreign Policy and Trade: The Communist Balkans in International Politics (Steven Rosefielde) 3:529-30

Cocks, Paul, Robert V. Daniels, and Nancy Whittier Heer, eds. The Dynamics of Soviet Politics ( $\mathrm{Zvi}$ Gitelman) 1:136-37 The "Confession" of Mikhail Bakunin, trans. by Robert C. Howes (Paul Avrich) 1:125-26

Connor, Walter D., and Zvi Y. Gitelman, with Adaline Huszczo and Robert Blumstock, Public Opinion in European Socialist Systems (Alex Simirenko) 4:690-91

Conquest, Robert, et al. Defending America (Alexander Dallin) 2:301-3

Conroy, Mary Schaeffer. Peter Arkad'evich Stolypin: Practical Politics in Late Tsarist Russia (Esther Kingston-Mann) 2:294-95

Cox, Arthur Macy. The Dynamics of Dètente: How to End the Arms Race (Joseph J. Kruzel) 3:504-5

Crockett, Dina B. Agreement in Contemporary Standard Russian (Richard L. Leed ) 2:362-63

Czigány, Lóránt. A magyar irodalom fogadtatása a viktoriánus Angliában, 1830 1914 (Thomas R. Mark) 4:721

Deane, Michael J. Political Control of the Soviet Armed Forces (Dale R. Herspring) 1:134-35

Desai, Padma. The Bokaro Steel Plant: A 
Study of Soviet Economic Assistance (M. Gardner Clark) 1:142-43

Dimitrov, Teodor Delchev. Ianuari Makgakhan: 1844-1878 g.: Biografia, dokumenti $i$ materiali (James F. Clarke) 4:71112

Dinić-Knežević, Dušanka. Položaj žena u Dubrovniku $u$ XIII $i X I V$ veku (Bariša Krekić) 4:705-6

Djilas, Milovan. Wartime (Walter R. Roberts) $3: 491-94$

Dmytryshyn, Basil. A History of Russia (Margaret H. Pertzoff) 2:290

Döry, Franciscus, comp. Decreta Regni Hungaricae / Gesetze und Verordnungen Ungarns, 1301-1457 (Joseph Held) 4:698-99

Dougherty, James E., and Diane K. Pfaltzgraff. Eurocommunism and the Atlantic Alliance (Charles Gati) 4:680-81

Doukas. Decline and Fall of Byzantium to the Ottoman Turks, trans. by Harry J. Magoulias (Deno J. Geanakoplos) 2:339

Dudko, Fr. Dmitrii. Our Hope (Donald W. Treadgold) 1:120-21

Eekman, Thomas, and Ante Kadić, eds. Juraj Križanić (1618-1683), Russophile and Ecumenic Visionary (Robert Auty) 1:15758

Elwood, Ralph Carter. Russian Social Democracy in the Underground: A Study of the RSDRP in the Ukraine, 19071914 (John S. Reshetar, Jr.) 4:670-71

Ernst, Raimund. Die Nordwestslaven und das fränkische Reich: Beobachtungen zur Geschichte ihrer Nachbarschaft und zur Elbe als nordöstlicher Reichsgrenze bis in die Zeit Karls des Grossen (Patrick J. Geary) 3:495

Fehér, Erzsébet, ed. József Attila válogatott levelezése (Lee Congdon) 2:331-32

Festschrift für Bernhard Stasiewski: Beiträge zur ostdeutschen und osteuropäischen Kirchengeschichte, 2:363

Field, Andrew. Nabokov: His Life in Part (William W. Rowe) 2:347-48

Foote, I. P., ed. M. E. Saltykov-Shchedrin: Selected Satirical Writings (Catherine Kulesov) $2: 345$

Frank, Tibor. The British Image of Hungary, 1865/1870 (Béla K. Király) 1:15657

Freeze, Gregory L. The Russian Levites: Parish Clergy in the Eighteenth Century (Samuel C. Ramer) 1:121-23

Gavrilović, Slavko, and Nikola Petrović, eds. Temišvarski Sabor 1790 (Roger Paxton) $1: 158-59$

Gerould, Daniel, ed. Twentieth-Century Polish Avant-Garde Drama: Plays, Scenarios, Critical Documents (Tymon Terlecki) $2: 356-57$

Gibert, Stephen P., et al. Soviet Images of America (Morton Schwartz) 3:502-3

Gibian, George, and H. W. Tjalsma, eds.
Russian Modernism: Culture and the Avant-Garde, 1900-1930 (Elena Sokol) 2:349-51

Glad, John, ed. Forum at Iowa on Russian Literature, vol. 1, no. 1, 1:177

Gnedin, E. Iz istorii otnoshenii mezhdu SSSR $i$ fashistskoi Germaniei (Alfred Erich Senn) 4:677

Gnedin, Evgenii. Katastrofa $i$ vtoroe rozhdenie: Memuarnye zapiski (Alfred Erich Senn) 4:677

Gorodetsky, Gabriel. The Precarious Truce: Anglo-Soviet Relations 1924-27 (Donald Lammers) 2:296-97

Gorodetzky, Nadejda. Saint Tikhon of $\mathrm{Za}$ donsk: Inspirer of Dostoevsky (Heinrich A. Stammler) 4:688-89

Granick, David. Enterprise Guidance in Eastern Europe: A Comparison of Four Socialist Economies (Michael Marrese) 3:51517

Grayson, Jane. Nabokov Translated: $A$ Comparison of Nabokov's Russian and English Prose (William W. Rowe) 2:347-48

Griffith, William E., ed. The Soviet Empire: Expansion and Détente (Paul Marantz) 4:679-80

The Grigorenko Papers: Writings by General P. G. Grigorenko and Documents on his Case (Andrei Amalrik) 2:316-17

Guerard, Albert J. The Triumph of the Novel: Dickens, Dostoevsky, Faulkner (Edward Wasiolek) 1:167

Gumilev, Nikolai. On Russian Poetry (Evelyn Bristol) 1:170

Gurley, John G. Challengers to Capitalism: Marx, Lenin, and Mao (Sidney Hook) $2: 307-8$

Hackel, Sergei. The Poet and the Revolution: Aleksandr Blok's "The Twelve" (Deming Brown) 1:170-71

Haddad, William W., and William Ochsenwald, eds. Nationalism in a Non-National State: The Dissolution of the Ottoman Empire (Allen Z. Hertz) 4:703-4

Hamilton, F. E. Ian. The Moscowe City Region (Jerome D. Fellmann) 2:315

Hammer, Richard. Bürger zweiter Klasse: Antisemitismus in der Volksrepublik Polen und der UdSSR (Paul W. Freedman) 4:696-97

Hardy, Deborah. Petr Tkachev, the Critic as Jacobin (Ivan Avakumovic) 2:296

Hawkes, Terence. Structuralism and Semiotics (Edward J. Brown) 3:534-35

Heckenast, Gusztáv, ed. Aus der Geschichte der ostmitteleuropäischen Bauernbewegung im 16.-17. Jahrhundert (Joseph Held) $1: 150$

Hegenbarth, Stanislawa. Landwirtschaftliche Zirkel und landwirtschaftliche Produktionsgenossenschaften in Polen (John A. Slater) 2:319-20

Hej1, František, ed. Ceskoslovensko-sovět- 
ské vatahy jako faktor mezinárodni politiky, 1917-1970 (Edward Taborsky) 3:522-23

Heller, Celia S. On the Edge of Destruction: Jews of Poland between the Two World Wars (Ezra Mendelsohn) 4:694-95

Henderson, W. O. The Life of Friedrich Engels (Angus Walker) 4:672-73

Hennessy, Richard. The Agrarian Question in Russia 1905-1907: The Inception of the Stolypin Reform (George L. Yaney) 4:674

Herman, K., et al. Nástin vatahu mezi československou a sovètskou vědou (Edward Taborsky) 3:522-23

Hidas, Peter I. The Metamorphosis of a Social Class in Hungary during the Reign of Young Franz Joseph (Istvan Deak) 3:526-27

Hitchins, Keith, et al, eds. Rumanian Studies: An International Annual of the Humanities and Social Sciences, vol. 3, 1973-1975, 2:364

Hodgson, Peter. From Gogol to Dostoevsky: Jakov Butkov, A Reluctant Naturalist in the 1840's (Victor Terras) 2:343-44

Holesovsky, Vaclav. Economic Systems: Analysis and Comparison (Steven Rosefielde) $2: 313$

Holquist, Michael. Dostoevsky and the Novel (Nathan Rosen) 4:712-15

Horecky, Paul L., and David H. Kraus, eds. East Central and Southeast Europe: $A$ Handbook of Library and Archival Resources in North America (Patricia Kennedy Grimsted) 1:146-48

Horvat, Josip. Ljudevit Gaj: Njegov život, njegovo doba (Elinor Murray Despalatović) $2: 334$

Horváth, János. A magyar irodalom fejlödéstörténete (Thomas R. Mark) 4:720

Hough, Jerry F. The Soviet Union and Social Science Theory (T. H. Rigby) $3: 507-9$

Isačenko, Alexander. Opera Selecta: Russische Gegenwartssprache, russische Sprachgeschichte, Probleme der slavischen Sprachwissenschaft (Horace G. Lunt) 4:723-24

Jangfeldt, Bengt. Majakovskij and Futurism: 1917-1921 (Henryk Baran) 3:536-37

Janos, Andrew C., ed. Authoritarian Politics in Communist Europe: Uniformity and Diversity in One-Party States (Richard Lowenthal) 4:682-83

Jelavich, Charles, and Barbara Jelavich. The Establishment of the Balkan National States, 1804-1920 (Hugh Seton-Watson) 4:702-3

Johnston, William M. The Austrian Mind: An Intellectual and Social History, 18481938 (Peter Pulzer) 1:154-55

Jones, David R., ed. Soviet Armed Forces Review Annual, vol. 1, 1977 (Dale R. Herspring) 1:134-35
Kacin-Wohinz, Milica. Primorski Slovenci pod Italijansko zasedbo 1918-1921 (Bogdan C. Novak) 4:710

Kagan-Kans, Eva. Hamlet and Don Quixote: Turgenev's Ambivalent Vision (James M. Curtis) 3:535

Kalmár, György I. Szociáldemokrácia nemzeti és nemzetiségi kérdés Magyarországon (1900-1914) (Gabor Vermes) 4:699. 700

Kaltakhchian, S. T. Leninizm o sushchnosti natsii $i$ puti obrazovaniia internatsional'noi obshchnosti liudei (Isabelle Kreindler) 4:686-87

Kann, Robert A., Béla K. Király, and Paula S. Fichtner, eds. The Habsburg Empire in World War I: Essays on the Intellectual, Military, Political and Economic Aspects of the Habsburg War Effort (Ioannis Sinanoglou) 2:329-30

Kansky, Karel Joseph. Urbanization under Socialism: The Case of Caechoslovakia (Kenneth T. Jackson) 2:327-28

Karlinsky, Simon, and Alfred Appel, Jr., eds. The Bitter Air of Exile: Russian Writers in the West, 1922-1972 (Vsevolod Setchkarev) 4:715-16

Kasack, Wolfgang. Lexikon der russischen Literatur $a b \quad 1917$ (Maurice Friedberg) $1: 169-70$

Kaser, Michael. Health Care in the Soviet Union and Eastern Europe (Mark G. Field) 1:143-45

Katz, Michael R. The Literary Ballad in Early Nineteenth-Century Russian Literature (Assya Humesky) 2:341-43

Keep, John L. H. The Russian Revolution: A Study in Mass Mobilization (Firuz Kazemzadeh) 4:668-69

Kellermann, Volkmar. Brücken nach Polen: Die deutsch-polnischen Beziehungen und die Weltmächte 1939-1973 (W. W. Kulski) $1: 150-51$

Khardzhiev, Nikolai, ed. $K$ istorii russkogo avangarda (The Russian Avant-Garde) (John E. Bowlt) 2:351-53

Khlebnikov, Velimir. Snake Train: Poetry and Prose (Elena Sokol) 2:349-51

Király, Béla K., and George Barany, eds. East Central European Perceptions of Early America (Robert W. Johannsen) $4: 693$

Kiss, Károly, and Tamás Katona, eds. $M_{0-}$ hács emlékezete (Janos M. Bak) 3:52526

Klyuev, Nikolai. Poems, trans. by John Glad (Lynn Visson) 4:717-18

Kofos, Evangelos. Greece and the Eastern Crisis, 1875-1878 (Harry J. Psomiades) $2: 340$

Komjathy, Anthony Tihamer. The Crises of France's East Central European Diplomacy, 1933-1938 (William E. Scott) $2: 317-18$

Kopysskii, Z. Iu. Sotsial'no-politicheskoe raz- 
vitie gorodov Belorussii v XVI-pervoi polovine XVII v. (David H. Miller) 4:671

Korbel, Josef. Twentieth-Century Czechoslovakia: The Meanings of Its History (J. W. Bruegel) 2:322-23

Kosinski, Leszek A., ed. Demographic Developments in Eastern Europe (Robert J. McIntyre) 3:517-18

Kovács, József. A szocialista magyar irodalom dokumentumai az amerikai magyar sajtóban 1920-1945 (S. B. Vardy) 2:33031

Kovalevsky, Pierre. Saint Sergius and Russian Spirituality (Donald W. Treadgold) $1: 120-21$

Krag, Erik. Dostoevsky: The Literary Artist (Victor Terras) 2:343-44

Krautheim, Hans-Jobst. Offentliche Meinung und imperiale Politik: Das britische Russlandbild 1815-1854 (René AlbrechtCarrié) 3:496-97

Kreusler, Abraham A. Contemporary Education and Moral Upbringing in the Soviet Union (O. Anweiler) 2:315

Krizman, Bogdan. Vanjska politika jugoslovenske države 1918-1941: Diplomatskohistorijski pregled (John C. Campbell) 3:531-32

Kubacki, Wacław. Z Mickiewiczem na Krymie (Thomas Eekman) 1:174-75

Kubinszky, Judit. Politikai Antiszemitizmus Magyarországon (1875-1890) (Keith Hitchins ) 3:528-29

Kula, Witold. An Economic Theory of the Feudal System: Towards a Model of the Polish Economy 1500-1800 (William E. Wright) 2:320-21

Lägreid, Annelies. Die russischen Lehnwörter im Slovenischen: Die in der ersten Hälfte des 19. Jahrhunderts übernommenen Wörter (Kenneth E. Naylor) 1:176

Lane, David. The Roots of Russian Communism: A Social and Historical Study of Russian Social-Democracy 1898-1907 (Reginald E. Zelnik) 2:292-93

Lane, David. The Socialist Industrial State: Towards a Political Sociology of State Socialism (Zdenek Suda) 2:309-10

Lévesque, Jacques. L'URSS et la révolution cubaine (Georges A. Fauriol) 1:14041

Libbey, James K. Alexander Gumberg and Soviet American Relations, 1917-1933 (C. Jay Smith) 2:299

La liberazione della Romania dal fascismo: $X X X$ anniversario (Vladimir Socor) 4:710-11

Lichtenstein, Erwin. Die Juden der Freien $S$ tadt Danzig unter der Herrschaft des $\mathrm{Na}$ tionalsozialismus (Anna M. Cienciala) 4:695-96

Litvinov, P., M. Meerson-Aksenov, and B. Shragin, eds. Samosoznanie: Sbornik statei (Marc Raeff) 1:116-19

Livshits, Benedikt. The One and a Half-
Eyed Archer, trans. by John E. Bowlt (Robert C. Williams) 2:353-54

Loebl, Eugen. My Mind on Trial (Sidney Hook) 2:323-25

Lopukhina-Rodzianko, T. Dukhovnye osnovy tvorchestva Solzhenitsyna (John B. Dunlop) $1: 168-69$

Lotman, Jurij. Semiotics of Cinéma (Ronald Levaco) 4:725-26

Lubrano, Linda L. Soviet Sociology of Science (Raymond Hutchings) 1:143

Luckyj, George S. N., ed. Discordant Voices: The Non-Russian Soviet Literatures, 19531973 (David Welsh) 3:539-40

Ludz, Peter Christian, ed., with the cooperation of Johannes Kuppe. DDR Handbuch (Arthur M. Hanhardt, Jr.) 1:149

Lukács, Georg. The Young Hegel: Studies in the Relations between Dialectics and Economics (G. L. Ulmen) 3:513-15

McAuley, Mary. Politics and the Soviet Union (T. H. Rigby) 3:509-10

McCauley, Martin. Khrushchev and the Development of Soviet Agriculture: The Virgin Land Programme 1953-1964 (Robert C. Stuart) 1:133-34

MccGwire, Michael, and John McDonnell, eds. Soviet Naval Influence: Domestic and Foreign Dimensions (Norman E. Saul) $1: 138-40$

MacKenzie, David, and Michael W. Curran. $A$ History of Russia and the Soviet Union (Margaret H. Pertzoff) 2:290

McLean, Hugh. Nikolai Leskov: The Man and His Art (Richard Freeborn) 1:165-66

Mal'tsev, Iu. Vol'naia russkaia literatura, 1955-1975 (John B. Dunlop) 3:537-38

Medlin, Virgil D., and Steven L. Parsons, eds. $V . D$. Nabokov and the Russian Provisional Government, 1917 (Rex A. Wade) 2:295-96

Megas, Georgios A. Die Ballade von der Arta-Brücke: Eine vergleichende Untersuchung (Felix J. Oinas) 2:360

Meissner, Boris, ed. Moskau-Bonn: Die Beziehungen zwischen der Sowjetunion und der Bundesrepublik Deutschland 19551973, Dokumentation, 2 vols. (Melvin Croan) 2:306-7

Mihailovich, Vasa D., ed. White Stones and Fir Trees: An Anthology of Contemporary Slavic Literatures (George Gibian) 2:35455

Mikasinovich, Branko, ed. Five Modern Plays (Mateja Matejić) 4:721-22

Mikulášek, Miroslav. Pobednyi smekh ( $O$ pyt shanrovo-sravnitel'nogo analiza dramaturgii $V$. $V$. Maiakovskogo) (Henryk Baran) 3:536-37

Milanović, Božo. Hrvatski narodni preporod u Istri (Bogdan C. Novak) 4:708-9

Milosz, Czeslaw. Emperor of the Earth: Modes of Eccentric Vision (Jerzy R. Krzyżanowski) 1:164 
Miłosz, Czesław. Utwory Poetyckie: Poems (Jerzy R. Krzyżanowski) 2:358

Morley, James William, ed. Deterrent Diplomacy: Japan, Germany, and the USSR, 1935-1940 (Ernst L. Presseisen) 3:501-2

Morris, Eric. The Russian Navy: Myth and Reality (Steve F. Kime) 3:506-7

Myrdal, Alva. The Game of Disarmament: How the United States and Russia Run the Arms Race (Joseph J. Kruzel) 3:504-5

Myrivilis, Stratis. Life in the Tomb (Kostas Myrsiades) 4:722-23

Nivat, Georges. Sur Soljenitsyne: Essais (John B. Dunlop) 1:168-69

Oxford Slavonic Papers, vol. 9, 1:178

Oxford Slavonic Papers, vol. 10, 2:363-64

Pascal, P. The Religion of the Russian People (Donald W. Treadgold) 1:120-21

Perrie, Maureen. The Agrarian Policy of the Russian Socialist-Revolutionary Party: From Its Origins through the Revolution of 1905-1907 (Esther Kingston-Mann) 2:294-95

Pil'niak, B. Izbrannye proizvedeniia (Gary L. Browning) 2:348-49

Přispěvky $k$ dějinám česko-ruských kulturnich styki /3 (Edward Taborsky) 3:522-23

Pritchett, V. S. The Gentle Barbarian: The Life and Work of Turgenev (Kathryn B. Feuer) 1:167-68

Rabinowitch, Alexander. The Bolsheviks Come to Power: The Revolution of 1917 in Petrograd (Samuel A. Oppenheim) 4:669-70

Radenić, Andrija. Iz istorije Srbije $i \mathrm{Voj}$ vodine, 1834-1914 (Gale Stokes) 3:530-31

Radenić, Andrija, ed. Dnevnik Benjamina Kalaja, 1868-1875 (Gale Stokes) 3:530-31

Rannit, Aleksis, and Eduard Wiiralt. Cantus firmus (Emery E. George) 4:718-20

Rasputin, Maria, and Patte Barham. Rasputin: The Man Behind the Myth, A Personal Memoir (David L. Ransel) 3:500

Raupach, Hans, ed. Jahrbuch der Wirtschaft Osteuropas (Josef C. Brada) 4:691-92

Rayfield, Donald. The Dream of Lhasa: The Life of Nikolay Przhevalsky (183988), Explorer of Central Asia (Joel M. Halpern) 2:291-92

Riasanovsky, Nicholas V. A Parting of Ways: Government and the Educated Public in Russia, 1801-1855 (John Keep) $1: 124-25$

Rigby, T. H., and R. F. Miller. Political and Administrative Aspects of the Scientific and Technical Revolution in the USSR (Linda L. Lubrano) 2:310-11

Rosdolsky, Roman. Die Bauernabgeordneten im konstituierenden österreichischen Reichstag 1848-1849 (Stanley Z. Pech) 3:527-28

Roździeński, Walenty. Officina Ferraria: $A$
Polish Poem of 1612 Describing the Noble Craft of Ironwork (Paul Bushkovitch) 2:321-22

Rubinstein, Alvin Z., ed. Soviet and Chinese Influence in the Third World (Ilana and Norman Kass) 1:141-42

Rusinow, Dennison. The Yugoslav Experiment, 1948-1974 (R. V. Burks) 2:335

Rüss, Hartmut. Adel und Adelsoppositionen im Moskauer Staat (Ann Kleimola) 3:496

Schlesinger, Rudolf. History of the Communist Party of the USSR: Past and Present (Robert W. Clawson) 4:685-86

Schmalstieg, William R. An Introduction to Old Church Slavic (Jan Louis Perkowski) 2:361-62

Schmaus, Alois. Gesammelte slavistische und balkanologische Abhandlungen, part 2 (David E. Bynum) 1:173-74

Schulz, Eberhard. Moskau und die europäische Integration (D. Brent Smith) 2:3045

Schweigler, Gebhard. Nationalbereusstsein in der $B R D$ und der $D D R$ (Richard L. Merritt) $3: 519-20$

Schweigler, Gebhard Ludwig. National Consciousness in Divided Germany (Richard L. Merritt) 3:519-20

Seaton, Albert. The Crimean War: $A$ Russian Chronicle (Walter M. Pintner) 4:672

Segel, Harold B., ed. Polish Romantic Drama: Three Plays in English Translation (Thomas H. Hoisington) 2:355-56

Seton-Watson, Hugh. Nations and States: An Enquiry into the Origins of Nations and the Politics of Nationalism (Firuz Kazemzadeh) 4:668-69

Shapiro, Jane P., and Peter J. Potichnyj, eds. Change and Adaptation in Soviet and East European Politics (Zvi Gitelman) $1: 136-37$

Shaw, Stanford J., and Ezel Kural Shaw. History of the Ottoman Empire and Modern Turkey, Volume II: Reform, Revolution, and Republic: The Rise of Modern Turkey, 1808-1975 (Roderic H. Davison) $1: 162-63$

Shein, Louis J., ed. and trans. Readings in Russian Philosophical Thought: Philosophy of History (Mary-Barbara Zeldin) $4: 687-88$

Shklifov, Blagoi. Kosturskiiat govor: Prinos kŭm prouchvaneto na iugozapadnite bŭlgarski govori (Ernest A. Scatton) 3:54445

Shragin, Boris, and Albert Todd, eds. Landmarks: A Collection of Essays on the Russian Intelligentsia, 1909 (Marc Raeff) $1: 128$

Shtemenko, S. M., General of the Soviet Army. The Last Six Months: Russia's Final Battles with Hilter's Armies in World War II (Harrison E. Salisbury) $1: 131-32$

Sidak, Jaroslav. Studije iz hrvatske povijesti 
XIX stoljeća (Wayne S. Vucinich) 4:7068

Sidak, Jaroslav. Studije o "Crkvi Bosanskoj" $i$ bogumilstwu (Wayne S. Vucinich) 4:7068

Skilling, H. Gordon. Czechoslovakia's Interrupted Revolution (Rudolf Vilem Perina) $1: 152-53$

Skrypnyk, Mykola. Statti $i$ promovy $z$ natsional'noho pytannia (Bohdan S. Wynar) $3: 520-21$

Slavica Hierosolymitana, Slavic Studies of the Hebrew University, vol. 1, 2:364

Sokolov, Sasha. A School for Fools, trans. by Carl R. Proffer (George Gibian) 3:538-39

Spengler, Ute. D. S. Merežkovskij als Literaturkritiker: Versuch einer religiösen $B e-$ grïndung der Kunst (Bernice Glatzer Rosenthal) 2:345-46

Spielman, John P. Leopold $I$ of Austria (Paula Sutter Fichtner) 3:524-25

Spira, Thomas. German-Hungarian Relations and the Swabian Problem: From Károlyi to Gömbös 1919-1936 (Eva S. Balogh) 4:700-702

Stanford Arms Control Group. International Arms Control: Issues and Agreements (William J. Spahr) 3:505-6

Statelova, Elena. Politika, Partii, Pechat na Bŭlgarskata Burzhoaziia 1909-1912 (John D. Bell) $2: 338-39$

Steele, Jonathan. Inside East Germany: The State that Came in from the Cold (Richard L. Merritt) 3:519-20

Stevens, Christopher. The Soviet Union and Black Africa (Ilana and Norman Kass) $1: 141-42$

Stites, Richard. The Women's Liberation Movement in Russia: Feminism, Nihilism, and Bolshevism, 1860-1930 (David L. Ransel) 3:498-500

Stoicescu, Nicolae. Vlad Tepes (Vladimir Socor) $2: 337-38$

Sugar, Peter F. Southeastern Europe under Ottoman Rule, 1354-1804 (Gale Stokes) $2: 332-34$

Suslov, Ilya. Here's to Your Health, Comrade Shifrin! (Elizabeth Klosty Beaujour) 1:172-73

Szabó, Dániel. A magyar álláspontok helye a Szerbiával szembeni hadicélok rendszerében, 1915-1918 (Gabor Vermes) 4:699700

Tertz, Abram [Andrei Sinyavsky]. A Voice from the Chorus (Heinrich A. Stammler) $1: 171-72$

Thornton, Judith, ed. Economic Analysis of the Soviet-Type System (Robert Campbell) $2: 314$

Tikhonov, Iu. A. Pomeshchich'i krest'iane v Rossii: Feodal'naia renta $v$ XVII-nachale $X V I I I$ v. (Ann Kleimola) 2:291

Todorov, Tzvetan. The Poetics of Prose (Rimvydas Silbajoris) 1:163
Tökés, Rudolf L., ed. Dissent in the USSR: Politics, Ideology, and People (Sidney Monas) 4:683-85

Treml, Vladimir G., ed. Studies in Soviet Input-Output Analysis (Michael Ellman) $3: 512-13$

Trepper, Leopold. The Great Game: Memoirs of the Spy Hitler Couldn't Silence (M. R. D. Foot) 1:130-31

Triska, Jan F., and Paul M. Johnson. Political Development and Political Change in Eastern Europe: $A$ Comparative Study (Zvi Gitelman) 1:136-37

Tucker, Robert C., ed. Stalinism: Essays in Historical Interpretation (Alec Nove) $1: 128-30$

Tucker, Robert W. The Inequality of $\mathrm{Na}$ tions (Angela Stent Yergin) 4:677-78

Turczynski, Emanuel. Konfession und $\mathrm{Na}$ tion: Zur Frühgeschichte der serbischen und rümanischen Nationsbildung (Philip J. Adler) 4:704-5

The Ukrainian Herald, Issue 7-8 (Spring 1974), An Underground Journal from Soviet Ukraine: Ethnocide of Ukrainians in the U.S.S.R. (Kenneth C. Farmer) 3:521-22

Ulam, Adam B. In the Name of the People: Prophets and Conspirators in Prerevolutionary Russia (E. H. Carr) 1:126-27

Ulbandus Review: A Journal of Slavic Languages and Literatures, vol. 1, no. 1 (Fall 1977), 3:547

Umbriet, Hans. Deutsche Militärverwaltungen 1938/39: Die militärische Besetzung der Tschechoslowakei und Polens (Norman Rich) 1:151-52

U.S. Army War College. National Security and Détente (Helmut Sonnenfeldt) 2:3034

Ŭabek Sovet Entsiklopediiasi, vols. 1-7: $\ddot{A}$-Nikelin (James Critchlow) 1:145-46

Vajda, Miklós, ed. Modern Hungarian Poetry (Tamás Aczél) 2:358-59

Valkenier, Elizabeth. Russian Realist Art: The State and Society: The Peredvizhniki and Their Tradition (John E. Bowlt) 3:545-46

Vanneman, Peter. The Supreme Soviet: Politics and the Legislative Process in the Soviet Political System (Max Mote) 2:308-9

Vardy, Steven Bela. Modern Hungarian Historiography (Richard E. Allen) 1:15556

Varsányi, Julius, ed., assisted by Stephen Krassay. Quest for a New Central Europe: $A$ Symposium (N. F. Dreisziger) $2: 318$

Vasil'eva, Evelina Karlovna. The Young People of Leningrad: School and Work Options and Attitudes (Ralph T. Fisher Jr.) 2:316

Vuković, Milan T., ed. Narodni običaji, ve- 
rovanja i poslovice kod Srba (Felix J. Oinas) $1: 159-60$

Wacyk, Nicholas. Ivan Franko: His Thoughts and Struggles (Danylo Husar Struk) $1: 174$

Wallace, William V. Czechoslovakia (Jörg K. Hoensch) 2:325-26

Warth, Robert D. Leon Trotsky (Alfred G. Meyer) 4:674-75

Weeks, Albert L. The Troubled Détente (Helmut Sonnenfeldt) 2:303-4

Widmer, Eric. The Russian Ecclesiastical Mission in Peking During the Eighteenth Century (Paul D. Steeves) 1:123-24

Wiles, P. J. D. Economic Institutions Compared (Steven Rosefielde) 2:286-89

Winters, Stanley B., and Joseph Held, eds., in collaboration with István Deák and Adam Wandruszka. Intellectual and Social Developments in the Habsburg Empire from Maria Theresa to World War I (Hugh Seton-Watson) 2:328-29
Witkiewicz, Stanislaw Ignacy. Czysta Forma w teatrze (E. J. Czerwinski) 3:540-41

Witkiewicz, Stanisław Ignacy. Insatiability: A Novel in Two Parts, trans. by Louis Iribarne (Ewa M. Thompson) 3:541-42

Worth, Dean S. A Bibliography of Russian Word-Formation (Frank Y. Gladney) 4:724-25

Žáček, Václav, ed. Češi a Jihoslované v mimulosti: Od nejstaršich dob do 1918 (Stanley Z. Pech) 1:153-54

Zaionchkovsky, Peter A. The Russian Autocracy Under Alexander III (Richard Wortman) 1:127

Zander, Valentine. St. Seraphim of Sarov (Donald W. Treadgold) $1: 120-21$

Zelinsky, Bodo. Russische Romantik (Z. Folejewski) 2:340-41

Zholkovsky, A. K., and Yu. K. Scheglov. Generating the Literary Text (Walter Schamschula) 1:164-65
Statement of Ownership, Management, and Cir culation required by the Act of August 12, 1970, Section 3685, Title 39, United States Code.

1. Title of publication: Slavic Review.

2. Date of filing: October 31, 1978.

3. Frequency of issue: Quarterly: March, June, September, December.

4. Location of known office of publication: 190 West 19th Ave, The Ohio State University, Columbus, Ohio $\mathbf{4 3 2 1 0 .}$

5. Location of the headquarters or general business offices of the publishers: 190 West 19th Ave., The Ohio State University, Columbus, Ohio 43210 .

6. Publisher: American Association for the Advancement of Slavic Studies, 190 West 19th
Ave., The Ohio State University, Columbus, Ohio 43210. Editor: James R. Millar, 911 West High, Room 200, University of Illinois, Urbana, Illinois 61801. Managing Editor: None.

7. Owner: American Association for the Advancement of Slavic Studies, 190 West 19th Ave., The Ohio State University, Columbus, Ohio 43210 .

8. Known bondholders, mortgagees, and other security holders owning or holding 1 percent or more of total amount of bonds, mortgages, or other securities: None.

9. For completion by nonprofit organizations authorized to mail at special rates (Section 132.122, Postal Manual): The purpose, function and nonprofit status of this organization and the exempt status for Federal income tax purposes have not changed during preceding 12 months.

\section{Extent and nature of ctrculation}

A. Total no. copies printed (net press run)

B. Paid circulation: (I) Sales through dealers and carriers, street vendors

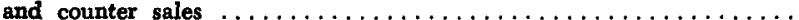

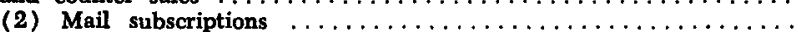

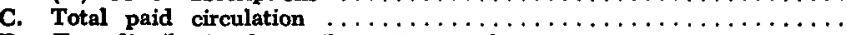

D. Free distribution by mail, carrier or other means: $\ldots \ldots \ldots \ldots \ldots$

E. Total distribution (

F. Office use, left-over, unaccounted, spoiled after printing $\ldots \ldots \ldots$

G. Total ( sum of $E$ \& $F-$ should equal net press run shown in $\mathbf{A}$ ) $\ldots$

$\begin{array}{cc}\begin{array}{c}\text { Ave. no. } \\ \text { copies each } \\ \text { issue in } \\ \text { preceding } \\ 12 \text { mos. }\end{array} & \begin{array}{c}\text { Actual no. } \\ \text { copies single } \\ \text { issue pub. } \\ \text { nearest } \\ \text { filing date }\end{array} \\ 4,451 & 4,594 \\ & \\ \text { None } & \text { None } \\ 3,815 & 3,885 \\ 3,815 & 3,885 \\ 94 & 94 \\ 3,909 & 3,979 \\ 542 & 615 \\ 4,451 & 4,594\end{array}$

11. I certify that the statements made by me above are correct and complete.

LnNDA B. Bowers, Assistant to the AAASS Executive Secretary

12. For completion by publishers mailing at the regular rates (Section 132.121, Postal Service Manual), 39 U. S. C. 3626 provides in pertinent part: "No person who would have been entitled to mail matter under former section 4359 of this title shall mail such matter at the rates provided under this subsection unless he files annually with the Postal Service a written request for permission to mail matter at such rates." In accordance with the provisions of this statute, I hereby request permission to mail the publication named in Item 1 at the phased postage rates presently authorized by $39 \mathrm{U}$. S. C. 3628 . (Signature of assistant to the executive secretary: LINDA B. Bowzrs). 